\title{
Foreign Direct Investment Dalam Pembangunan Ekonomi Indonesia Perspektif Ekonomi Islam
}

\section{Foreign Direct Investment In Indonesia Economic Development, Islamic Economic Perspective}

\author{
Lira Zohara \\ Hukum Ekonomi Syariah, Fakultas Syariah dan Hukum, UIN Walisongo, Semarang, 50185, Indonesia \\ E-mail: lira.zohara@walisongo.ac.id
}

Naskah masuk: 2021-03-16 Naskah diperbaiki: 2021-04-03 Naskah diterima: 2021-04-17

\begin{abstract}
ABSTRAK
Indonesia merupakan negara berkembang yang membutuhkan dana cukup besar untuk melaksanakan pembangunan. Untuk mendorong pembangunan Indonesia memperoleh pembiayaan dari dalam negeri maupun luar negeri. FDI ( Foreign Direct Investment) merupakan salah satu sumber dana alternatif dalam meningkatkan pembangunan di Indonesia. FDI adalah salah satu jenis investasi asing yang memberikan kontribusi besar melalui transfer asset dan manajemen, serta transfer tekhnologi sehingga dapat mendorong perekonomian Indonesia. Investasi dalam Islam merupakan suatu kegiatan yang disarankan, hal ini dikarenakan dengan adanya investasi maka harta akan lebih produktif dan bermanfaat bagi orang lain. Tujuan yang hendak dicapai dalam penelitian ini adalah meninjau bagaimana FDI dalam pembangunan ekonomi dilihat dari perspektif ekonomi Islam. Dalam penelitian ini menggunakan metode Library Research, yaitu suatu penelitian yang memanfaatkan sumber perpustakaan untuk memperoleh data penelitiannya. Data diperoleh dari buku, makalah atau artikel, Jurnal, majalah, web (internet) ataupun informasi lainnya yang berhubungan sengan judul penulisan. Foreign Direct Investment mempunyai dampak jangka pendek dan jangka panjang dalam perekonomian Indonesia. Dalam jangka pendek FDI belum begitu memberikan kontribusi yang cukup baik dalam perekonomian Indonesia, hal ini dikarenakan masih tingginya impor terhadap barang baku yang digunakan. FDI dalam jangka panjang diyakini dapat membuka lapangan pekerjaan bagi tenaga kerja terdidik karena adanya pendirian perusahaan dan pembangunan pabrik baru. Dalam Islam tidak terdapat pengertian investasi secara spesifik namun menurut Islam investasi merupakan suatu kegiatan/tindakan yang sangat disarankan kepada umat muslim, hal ini dikarenakan dengan adanya investasi yang dilakukan maka harta cenderung lebih berkembang/produktif dan dapat lebih bermanfaat bagi orang lain.
\end{abstract}

Kata kunci: Ekonomi Pembangunan, Foreign Direct Investment, Ekonomi Islam

\section{ABSTRACT}

Indonesia is a developing country that requires a large amount of funds to carry out development. To encourage development, Indonesia obtains domestic and foreign financing. FDI (Foreign Direct Investment) is an alternative source of funds in enhancing development in Indonesia. FDI is a type of foreign investment that makes a major contribution through asset and management transfers, as well as technology transfer so as to boost the Indonesian economy. Investing in Islam is a recommended activity, this is because with the investment, assets will be more productive and useful for others. The aim of this research is to examine how FDI in economic development is viewed from an Islamic economic perspective. In this study using the Library Research method, which is a study that utilizes library sources to obtain research data. Data obtained from books, papers or articles, journals, magazines, web (internet) or other information related to the title of 
writing. Foreign Direct Investment has short-term and long-term impacts on the Indonesian economy. In the short term, FDI has not contributed significantly to the Indonesian economy, this is due to the high imports of raw materials used. In the long term, FDI is believed to be able to create jobs for educated workers due to the establishment of companies and construction of new factories. In Islam there is no specific meaning of investment but according to Islam investment is an activity / action that is highly recommended to Muslims, this is because with the investment made, assets tend to be more developed / productive and can be more beneficial to others.

Keywords: Economic Develoment, Foreign Direct Investment, Islamic Economic

Copyright (C) 2021 Program Studi Ekonomi Perbankan Islam, FEB Universitas Majalengka. All rights reserved.

\section{Pendahuluan}

Pertumbuhan ekonomi merupakan salah satu tolok ukur dari keberhasilan pembangunan di suatu Negara. Pertumbuhan ekonomi menggambarkan dampak nyata dari kebijakan pembangunan yang dilaksanakan khususnya dalam bidang ekonomi. Tanpa adanya pertumbuhan ekonomi, maka pembangunan ekonomi kurang bermakna. ${ }^{1}$

Pembangunan ekonomi diperlukan oleh suatu negara dalam rangka untuk meningkatkan taraf hidup dan kesejahteraan masyarakat, dengan cara mengembangkan semua bidang yang ada dalam suatu negara. Menurut Todaro pembangunan merupakan suatu proses multi dimensional yang melibatkan perubahan-perubahan besar dalam struktur sosial, sikap mental dan lembagalembaga nasional termasuk percepatan/akselerasi pertumbuhan ekonomi, pengangguran, ketimpangan dan pemberantasan kemiskinan yang absolut. ${ }^{2}$

Grafik 1.1. Pertumbuhan Ekonomi Indonesia

\footnotetext{
${ }^{1}$ Gerald Meier, Leading Issues in Economic Development - Gerald M. Meier; James E. Rauch Oxford University Press, accessed February 5, 2021, https://global.oup.com/academic/product/leadingissues-in-economic-development9780195179606 ?cc $=$ us\&lang=en\&.

${ }^{2}$ Michael P Todaro, Pembangunan Ekonomi Di Dunia Ketiga Edisi Keenam, Alih Bahasa Oleh Haris Munandar, Penerbit Erlangga, Jakarta, 1997, https://books.google.co.id/books?id=M9ofKAAACA AJ.
}

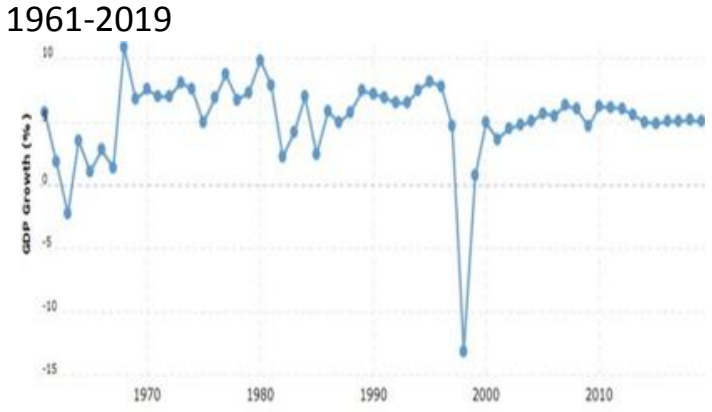

Sumber: Bank Indonesia

Pada awal tahun 1965 sampai dengan awal tahun 1997-an, perekonomian Indonesia tumbuh dengan kondisi yang menggembirakan dimana prosentase pertumbuhan ekonomi rata-rata hampir 7 persen. Hal ini menyebabkan Indonesia bersama negaranegara Asia lainnya (Korea Selatan, Hongkong, Taiwan, Singapura, Malaysia, Thailand dan Filipina) dikatakan sebagai keajaiban ekonomi dan Indonesia menjadi salah satu pilar penentu perekonomian dunia mengimbangi negaranegara maju.

Namun pertengahan 1997, terjadi krisis Finansial Asia yang mengakibatkan dampak negatif untuk perekonomian Indonesia dimana menyebabkan kontraksi pada Produk Domestik Bruto (PDB) sebesar -13,6 persen pada tahun 1998. Krisis Finansial tersebut diawali di Thailand dimana terjadi pemborongan dollar secara besar-besaraan yang menyebabkan permintaan dollar semakin tinggi dan nilai mata uang regional semakin melemah. Kondisi ini menyebabkan 
kepercayaan investor asing menurun untuk tetap menanamkan investasinya di Indonesia. Kemudian banyak investor asing yang melakukan penarikan dana dalam jumlah besar secara tiba-tiba sehingga menyebabkan pesimisme prospek perekonomian regional dan menyebabkan mata uang rupiah melemah secara drastis.

Perkembangan pertumbuhan ekonomi tahun 2000 sampai 2004 mulai pulih setelah terjadinya krisis finansial Asia dengan rata-rata pertumbuhan PDB sebesar 4,6 persen per tahun. Dimana investor asing mulai kembali menanamkan investasinya di Indonesia. Tahun 2010-2015 terjadi perlambatan ekonomi karena adanya era boom komoditas yaitu jatuhnya harga komoditas andalan Indonesia (minyak sawit, karet, batubara dan mineral). Akselesari pertumbuhan ekonomi terjadi pada tahun 2015-2019, namun pada kuartal terakhir tahun 2019 kondisi perekonomian global melambat dan mempengaruhi perekonomian Indonesia dampak dari perang dagang antara Amerika Srikat dan Tiongkok.

Indonesia merupakan salah satu negara yang sedang berkembang, untuk mewujudkan pembanguanan nasionalnya diperlukan dana yang cukup besar. Kebutuhan dana yang besar tersebut terjadi karena adanya upaya untuk mengejar ketertinggalan pembangunan dari negara-negara maju. Indonesia masih belum mampu menyediakan dana pembangunan tersebut, sehingga menggali sumber-sumber pembiayaan dari luar negeri.

FDI (Foreign Direct Investment) merupakan salah satu indikator ekonomi dan variabel yang signifikan pengaruhnya terhadap pertumbuhan ekonomi suatu negara termasuk Indonesia. Investasi menjadi begitu penting karena memiliki efek langsung yang sangat penting dimasa yang akan datang bagi perkembangan ekonomi. Banyaknya perusahaan PMA langsung (FDI) akan memberikan dampak yang cukup besar bagi perkembangan masyarakat Indonesia yang berfungsi sebagai penyerap tenaga kerja, memutar aset faktor-faktor produksi seperti tanah, gedung dan sebagainya yang awalnya tidak terpakai. Selain itu FDI berperan dalam proses alih teknologi, dimana teknik produksi yang awalnya belum dikenal disuatu negara, melalui penanaman modal asing menjadi dikenal. $^{3}$

Selain itu Penanaman modal asing langsung (FDI) juga merupakan salah satu sumber penting yang menjadi sasaran pemerintah untuk membantu proses pembangunan di Indonesia karena sangat berpengaruh terhadap pulihnya perekonomian Indonesia. Hal ini tidak hanya mempengaruhi keinginan investor baru untuk menanamkan modalnya di Indonesia tetapi juga mempengaruhi iklim investasi di Indonesia secara keseluruhan baik investasi yang langsung maupun investasi tidak langsung. Oleh karena itu Investasi asing langsung (FDI) di indonesia mempunyai pengaruh yang sangat luas dan penting, tidak hanya pada sektor regional tetapi juga pada sektor nasional, sektor ketenagakerjaan bahkan sektor internasional.

\section{Foreign Direct Investment}

Tidak dipungkiri bahwa kemajuan ekonomi Indonesia tidak lepas dari peranan Foreign Direct Investment atau penanaman modal asing. Dalam Foreign Direct Investmen (FDI) tidak hanya membawa modal tetapi tekhnologi dan networking pemasaran produknya. Sejak awal dibukanya FDI di Indonesia sekitar akhir tahun 1960-an aliran masuk FDI ke Indonesia mengalami pertumbuhan yang signifikan dan sangat berkontribusi terhadap pertumbuhan ekonomi Indonesia sampai saat ini.

Tabel 1. Perkembangan FDI di Indonesia (dalam US\$ million)

\begin{tabular}{l}
\hline Tahun \\
\hline \\
Suryawati, “Peran Investasi Asing Langsung \\
Asia Timur" 5, no. 1 (1992): 8.
\end{tabular}




\begin{tabular}{|c|c|}
\hline 2009 & 4877.4 \\
\hline 2010 & 15292.1 \\
\hline 2011 & 20564.9 \\
\hline 2012 & 21200.8 \\
\hline 2013 & 23281.7 \\
\hline 2014 & 25120.7 \\
\hline 2015 & 19779.1 \\
\hline 2016 & 4541.7 \\
\hline 2017 & 20510.3 \\
\hline 2018 & 18909.8 \\
\hline 2019 & 24946.9 \\
\hline
\end{tabular}

Sumber: The World Bank

Masuknya FDI di Negara Asia Tenggara karena melimpahnya sumber daya alam dan adanya pasar yang potensial untuk mendirikan perusahaan multinasional. Perkembangan FDI di Indonesia sangat fluktuatif dari tahun 2009 2019. Apabila FDI turun biasanya disebabkan oleh kondisi keamanan di Indonesia dan akan berdampak pada tingkat suku bunga serta nilai tukar.

Penanaman modal asing mulai masuk di Indonesia melalui UU Penanaman Modal Asing (PMA) No.1 tahun 1967, dengan meningkatnya arus modal asing di Indonesia UU tersebut diubah dengan UU tentang Penanaman Modal No. 25 Tahun 2007. Dalam pembaharuan UU tersebut pemerintah berupaya untuk menyederhanakan proses perizinan penanaman modal untuk meningkatkan investasi dalam negeri. Foreign Direct Investmen (FDI) berpengaruh positif terhadap tenaga kerja pada industri-industri penerima, dimana dalam FDI tersebut terdapat transfer tekhnologi, keterampilan manajerial, dan terbangunnya skill tertentu pada tenaga kerja lokal.

Masuknya FDI ke Negara pendonor biasanya dilakukan melalui tiga cara ${ }^{4}$, yaitu:

a. Perusahaan Multinasional (Akuisisi atau pendirian perusahaan diluar negari)

\footnotetext{
${ }^{4}$ Annisa Puriadji, "FDI Di Indonesia - International Business Management," accessed February 7, 2021, https://bbs.binus.ac.id/ibm/2017/11/fdi-diindonesia/.
}

b. Penyediaan modal bagi perusahaan di suatu Negara

c. Pembelian saham di Negara tertentu dengan minimal saham yang dibeli adalah $10 \%$.

Menurut Feldstein (2000) ada beberapa keuntungan dari adanya Foregn Direct Investmen (FDI) ${ }^{5}$, yaitu:

1. Aliran modal tersebut mengurangi resiko dari kepemilikan modal dengan melakukan deversifikasi melalui investasi.

2. Integrasi global pasar dapat memberikan spread terbaik dalam pembentukan corporate governance, accounting rules, dan legalitas.

3. Mobilitas modal secara global membatasi kemampuan pemerintah dalam menciptakan kebijakan yang salah.

Jenis FDI, sebagai berikut:

1. FDI Vertikal

Merupakan investasi asing yang berhubungan dengan bahan baku dan tenaga kerja dalam suatu Negara, dimana Perusahaan akan melakukan produksi dinegara-negara yang memiliki biaya tenaga kerja yang rendah, kemudian hasil produksi di Negara tersebut akan disalurkan kembali ke Negara induk.

\section{FDI Horizontal}

Merupakan penanaman modal asing yang berusaha mendekati pasar dengan tujuan untuk mengurangi biaya transportasi dan biaya perdagangan antar negara. ${ }^{6}$

Menurut David K Eiteman FDI juga dibedakan berdasarkan motivasi yang melatarbelakangi investor asing:

a. Motif strategis, investor berusaha untuk mendekati lokasi bahan baku, dan pasar sehingga akan tercapai efisiensi dalam produktifitasnya.

\footnotetext{
${ }^{5}$ Martin Feldstein, "Aspects of Global Economic Intergration: Outlook for the Future," NBER Working Papers, 2000, https://ideas.repec.org/p/nbr/nberwo/7899.html.

${ }^{6}$ Yati Kurniati, Andry Prasmuko, and Yanfitri, "Determinan FDI (Faktor-Faktor Yang Menentukan Investasi Asing Langsung)," Bank of Indonesia Working Paper 6 (2007): 1-60.
} 
b. Motif perilaku merupakan suatu rangsangan lingkungan eksternal dan yang lain dari organisasi didasarkan pada kebutuhan dan komitmen individu atau kelompok.

c. Motif ekonomi merupakan motif untuk memperoleh laba sebanyak-banyaknya baik dalam jangka panjang maupun jangka pendek. ${ }^{7}$

\section{Kajian Teori}

\section{Teori Pertumbuhan Ekonomi Neo-Klasik}

Teori pertumbuhan neo klasik berkembang sejaktahun 1950-an. Teori ini berkembang berdasarkan analisis mengenai pertumbuhan ekoomi menurut pandangan ekonomi klasik. Ekonom yang menjadi perintis dalam perkembangan teori tersebut adalah Robert Solow dan Trevor Swan.

Model Pertumbuhan solow merupakan model pertumbuhan ekonomi yang membahas mengenai makro ekonomi yaitu dari ketersediaan modal, angkatan kerja, serta kemajuan teknologi dalam kegiatan perekonomian. Menurut Solow dan Swan, bahwa pertumbuhan ekonomi tergantung kepada pertambahan penyediaan faktor-faktor produksi (penduduk, tenaga kerja dan akumulasi modal) serta tingkat kemajuan tekhnologi. Dengan kata lain, sampai dimana perekonomian akan berkembang bergantung pertambahan penduduk, akumulasi modal dan kemajuan tekhnologi. ${ }^{8}$

Tingkat tabungan yang tinggi dalam suatu Negara tidak akan baik apabila tidak diinvestasikan, karena uang hanya mengendap tanpa memperoleh hasil. Dengan adanya kegiatan investasi pemerintah dapat memaksimalkan tabungan tersebut untuk

\footnotetext{
${ }^{7}$ David K Eiteman, "Penanaman Modal Asing Dan Penanaman Modal Dalam Negeri | Sere," accessed February 11, 2021, https://sereeeias.wordpress.com/2013/05/31/pena naman-modal-asing-dan-penanaman-modal-dalamnegeri/.

${ }^{8}$ Lincolin Arsyad, Ekonomi Pembangunan Universitas Terbuka Repository, accessed February 11, 2021, http://repository.ut.ac.id/3950/.
}

meningkatkan kesejahteraan masyarakat. Pemerintah atau pembuat kebijakan harus memahami bahwa individu pada umumnya hanya peduli pada konsumsi (bukan modal dan jumlah output). ${ }^{9}$

\section{Model Pertumbuhan Ekonomi Harrod-Domar} Model Harrod-Domar merupakan perluasan dari analisis Keynes mengenai kegiatan ekonomi secara nasional dan tenaga kerja. Harrod-Domar menganalisis syaratsyarat yang diperlukan agar perekonomian bisa tumbuh dan berkembang dengan mantang (steady growth) dalam jangka panjang. Model pertumbuhan Harrod-Domar dibangun berdasarkan pengalaman negara maju, HarrodDomar memberikan peranan kunci pada investasi di dalam proses pertumbuhan ekonomi, khususnya mengenai peran ganda yang dimiliki investasi. Pertama, investasi menciptakan pendapatan yang merupakan dampak dari penawaran, dan kedua, investasi memperbesar kapasitas produksi perekonomian dengan cara meningkatkan stok modal yang merupakan dampak dari penawaran. ${ }^{10}$

\section{Pertumbuhan Ekonomi dalam Islam}

Islam mendefinisikan pertumbuhan ekonomi sebagai perkembangan yang terus menerus dari faktor produksi secara benar yang mampu memberikan kontribusi bagi kesejahteraan manusia. ${ }^{11}$ Dapat diartikan bahwa pertumbuhan ekonomi menurut islam merupakan sebagai sarana untuk meningkatkan kesejahteraan manusia tanpa memandang adanya ras, agama dan bangsa.

Pencapaian pertumbuhan ekonomi

\footnotetext{
${ }^{9}$ Mankiw Gregory, Makroekonomi Mankiw Edisi 6 Pdf 12, n.d.

${ }^{10}$ Gregory.

${ }^{11}$ Muhammad Abul Hasan, Economic Development in Islam /Abulhasan Muhammad Sadeq. - National Library, accessed February 11, 2021, https://www.nlb.gov.sg/biblio/5759644.
} 
tidak hanya dilihat dari matari atau hasil namun dilihat dari sisi kehidupan agama, social dan kemasyarakatan. Apabila pertumbuhan ekonomi yang terjadi justru menimbulkan adanya keterbalakangan dan kekacauan sehingga jauh dari nilai keadilan dan kemanusiaan maka dipastikan bahwa pertumbuhan tersebut tidak sesuai dengan ekonomi Islam. ${ }^{12}$

\section{Metode Penelitian}

Penelitian ini adalah library research (penelitian kepustakaan), library

research adalah serangkaian kegiatan yang berkenaan dengan metode pengumpulan data pustaka, membaca dan mencatat serta mengolah bahan penelitiannya. Library Research merupakan suatu penelitian yang memanfaatkan sumber perpustakaan untuk memperoleh data penelitiannya. ${ }^{13}$

1. Data dan Sumber Data

Studi dokumentasi adalah tekhnik pengumpulan data yg tidak langsung ditujukan pada sebuah penelitian, namun melalui dokumen. Dokumen yang digunakan dapat berupa buku harian, surat pribadi, laporan, notulen rapat, catatan khusus dalam pekerjaan social dan dokumen lainnya. ${ }^{14}$

2. Tekhnik Pengumpulan Data

Tekhnik pengumpulan data dengan identifikasi wacana dari buku-buku, makalah atau artikel, majalah, jurnal, web (internet) ataupun informasi lainnya yang berhubungan sengan judul penulisan. ${ }^{15}$

\footnotetext{
${ }^{12}$ Irfan Syauqi Beik and Laily Dwi Arsyianti, “Ekonomi Pembangunan Syariah," 2017, 266, https://opac.perpusnas.go.id/DetailOpac.aspx?id=9 69369.

${ }^{13}$ Saifudin Azwar, Metode Penelitian, accessed February 12, 2021, http://adl.aptik.or.id/default.aspx?tabID=61\&src=k \&id=302766.

${ }^{14}$ Azwar.

${ }^{15}$ Azwar.
}

\section{Hasil dan Pembahasan}

Aliran FDI dunia mulai mengalami peningkatan pada tahun 1990-an, dalam FDI tidak hanya membawa modal tetapi juga teknologi dan networking pemasaran produknya. Pada tahun 2000 mulai banyak banyak Negara pendonor yang mulai investasi dalam bentuk FDI ke Negara-negara berkembang seperti Inggris, Jerman, Spanyol, Belanda dan Perancis. Masuknya FDI dipengaruhi oleh kondisi dari Negara penerima FDI antara lain kondisi pasar, ketersediaan sumberdaya, dan kebijakan terkait dengan perdagangan dan industri. Masuknya FDI ke Negara berkembang tidak terlepas dari tingginya laju pertumbuhan ekonomi Negara tersebut. Dengan adanya pertumbuhan ekonomi yang tinggi, biaya tenaga kerja yang murah dan produktif serta kestabilan nilai tukar yang membuat Negara donor tertarik melakukan investasi.

Pada awal masuknya FDI ke Negara tuan rumah memiliki kecenderungan yang tinggi untuk melakukan impor. Dimana akan Negara tuan rumah akan melakukan impor peralatan, mesin, penyedia fasilitas lainnya dan bahan baku dikarenakan Negara tuan rumah tidak memiliki bahan baku untuk produksi. Pada tahap selanjutnya akan menyesuaikan bahan baku agar tidak terlalu banyak melakukan kegiatan impor karena ditakutkan adanya ketergantungan impor sehingga akan menimbulkan dampak yang merugikan.

Banyak sekali perdebatan mengenai dampak dari Foreign Direct Investment yang terjadi di Indonesia. Dalam teori klasik pertumbuhan ekonomi oleh Adam Smith menyebutkan bahwa terdapat tiga factor penentu dari pertumbuhan ekonomi yaitu (i) sumberdaya alam, (ii) sumberdaya manusia, dan (iii) barang modal. FDI memberikan dampak yang positif karena adanya transfer tekhnologi, dan keahlian manajerial ke Negara Indonesia. Jika dilihat FDI itu sendiri, merupakan investasi barang modal atau investasi riil dalam bentuk mendirikan 
perusahaan, membangun pabrik, dan membeli bahan baku. Sehingga dengan adanya FDI disebut-sebut mampu untuk meningkatkan pertumbuhan ekonomi Indonesia.

Islam sebagai agama Allah, mengatur kehidupan manusia baik kehidupan didunia maupun diakhirat. Al Qur'an dan As-sunah merupakan pedoman bagi kaum muslimin dalam menjalani kehidupan, sehingga dapat diartikan bahwa ekonomi islam merupakan sistem ekonomi berdasar pada Al Qur'an dan Hadist dan memiliki tujuan untuk menyediakan kebutuhan manusia di dunia dan akhirat (al falah). ${ }^{16}$

Islam merupakan agama yang mendukung adanya kegiatan investasi, karena dalam ajaran islam tidak diperbolehkan menimbun harta dan Islam memberikan kelonggaran sebesar-besarnya sepanjang kegiatan tersebut berada dalam koridor dan tatanan yang benar. Islam memandang bahwa modal adalah sesuatu yang bersifat stock concept (tetap). Sedangkan uang dalam Islam adalah suatu yang bersifat flow concept, artinya dimana uang merupakan sesuatu yang harus selalu mengalir. Maka semakin tinggi perputaran uang maka pergerakan ekonomi semakin baik. Sehingga Islam menganjurkan dilaksanakan qard sebagai sesuatu yang dapat memutarkan uang. ${ }^{17}$

Jenis-Jenis Penanaman Modal Dalam Islam

Jenis-jenis kerjasama dan Penanaman

Modal yang dikenal dalam hukum Islam (al Fiqh) sebagai berikut:

\footnotetext{
${ }^{16}$ Nurul Huda dkk, Ekonomi Mikro Islam, Pendekatan Teoretis, 2018, http://library.um.ac.id/freecontents/index.php/buku/detail/ekonomi-makroislam-pendekatan-teoretis-nurul-huda-et-al34324.html.

${ }^{17}$ Adiwarman Karim, Ekonomi Islam Suatu Kajian Ekonomi Makro, 2002, http://library.umy.ac.id/koleksi/view/97279/ekono mi-islam-suatu-kajian-kontemporer.
}

\section{a. Al Mudharabah}

Al Mudharabah merupakan penyerahan modal oleh pemilik modal kepada pengelola modal dalam bentuk perdagangan, dimana keuntungan akan dibagi antara pemilik modal dengan pengelola modal sebagaimana dalam perjanjian oleh keduanya, dan apabila ada kerugian akan ditanggung oleh pemilik modal. ${ }^{18}$

b. Al-Muzara'ah

Arti dari Al-Muzara'ah adalah menyerahkan lahan kepada seseorang yang akan mengelola lahan tersebut dengan memberikan bagian dari hasil panennya seperti setengah, sepertiga atah lebih sedikit sesuai dengan keseakatan bersama. ${ }^{19}$

\section{c. Asy-Syirkah}

Menurut bahasa Asy-Syirkah dalam

buku Fiqh kontemporer dari Kitab AlMuamalat Al Madiyyah Wa Al Abadiyyah Terjemahan Ali Fikri adalah mencampurkah harta antara sehingga keduanya tidak dapat membedakan antara miliknya dengan milik orang lain. ${ }^{20}$

Asy-Syirkah menurut jenisnya dibagi menjadi Syirkah Amla' dan Syirkah 'Ukud.

\section{1) Syirkah Amla'}

Syirkah Amla' ; yaitu dua orang atau lebih memiliki benda/harta, yang bukan disebabkan akad syirkah. Perkongsian pemilikan ini tercipta karena warisan, wasiat, membeli bersama, diberi bersama, atau kondisi

\footnotetext{
${ }^{18}$ Abdurrahman Al-Jaziri, Al Fiqh Ala Al Madzahib Al Arba'ah, Juz 4, (Dar al Hadits, 2000).

${ }^{19}$ Sayyid Sabiq, Fiqh Sunnah 3 Trj. Mahyuddin Syaf (Al Ma\'arif, 1993).

${ }^{20}$ Sri Sudiarti, Fiqih Muamalah Kontemporer, Syariah Nurjati Press, 2018, https://www.academia.edu/download/51037950/fi qih_muamalah_may.pdf\%0Ahttps://isbn.perpusnas .go.id/Account/SearchBuku?searchCat=ISBN\&searc hTxt=978-602-14858-3-

5\%0Ahttp://repository.uinsu.ac.id/5517/1/FIQH MUAMALAH KONTEMPORER.pdf.
} 
lainnya yang berakibat pemilikan satu asset oleh dua orang atau lebih. ${ }^{21}$

a) Syirkah ijbariyah, yaitu syirkah yang terjadi bukan oleh perbuatan dua pihak atau lebih sebagaimana syirkah ikhtiyar di atas, tetapi mereka memilikinya secara otomatis, terpaksa dan tidak bisa mengelak (jabari), seperti dua orang yang mewarisi sesuatu, sehingga kedua orang tersebut sama-sama mempunyai hak atas harta warisan tersebut. ${ }^{22}$

b) Syirkah Ikhtiyariyah yaitu syirkah yang terjadi oleh perbuatan dua orang yang bekerjasama, seperti manakala keduanya membeli, diberi atau diwasiati lalu keduanya menerima, sehingga sesuatu tersebut menjadi hak milik bersama bagi keduanya. ${ }^{23}$

\section{2) Syirkah Uqud}

Syirkah 'Ukud adalah transaksi yang dilakukan oleh dua orang atau lebih untuk berserikat dalam permodalan dan keuntungan. Para ulama berbeda pendapat dalam membagi jenis-jenis syirkah 'ukud. Menurut Malikiyah, syirkah 'ukud ada 4 macam, yaitu: ${ }^{24}$

\section{a) Syirkah Inan}

Syirkah 'Inan, Adalah kontrak antara dua orang atau lebih. Setiap pihak memberikan suatu porsi dari keseluruhan dana dan berpartisipasi dalam kerja. Kedua pihak berbagi dalam keuntungan dan kerugian sebagaimana disepakati di antara mereka. Namun porsi masing-masing pihak, baik dalam dana, hasil kerja maupun bagi hasil berbeda, sesuai dengan kesepakata. ${ }^{25}$

\section{b) Syirkah Mufawadhah}

Adalah dua orang atau lebih melakukan serikat bisnis dengan syarat adanya kesamaan dalam permodalan, pembagian keuntungan dan kerugian, kesamaan kerja, tangunggung jawab dan beban hutang. Satu

\footnotetext{
${ }^{21}$ Sudiarti.

${ }^{22}$ Sudiarti.

${ }^{23}$ Sudiarti.

${ }^{24}$ Sudiarti.

${ }^{25}$ Sudiarti.
}

pihak tidak dibenarkan memiliki saham (modal) lebih banyak dari partnernya. ${ }^{26}$

\section{c) Syirkah 'Amal/abdan}

Adalah kontrak kerja sama dua orang atau lebih untuk menerima pekerjaan secara bersama dan berbagi keuntungan dari pekerjaan itu, seperti tukang jahit, tukang besi, tukang kayu, dan arsirtek. ${ }^{27}$

\section{d) Syirkah Wujuh}

Adalah kontrak bisnis antara dua orang atau lebih yanag memiliki reputasi dan prestise baik, di mana mereka dipercaya untuk mengembangkan suatu bisnis tanpa adanya modal. Misalnya, mereka dipercaya untuk membawa barang dagangan tanpa pembayaran cash. $^{28}$

MUI mengeluarkan fatwa yaitu DSN-MUI No. 80/DSN-MUI/III/2011 dimana mengatur bagaimana memilih investasi yang dibolehkan syariat serta melarang kegiatan yang bertentangan dengan prinsip syariah dalam kegiatan investasi dan bisnis, yaitu: ${ }^{29}$

1) Maisir, merupakan kegiatan yang dilarang karena mengarah pada perjudian dimana yang menang judi akan memperoleh taruhannya.

2) Gharar, berarti keraguan atau ketidakpastian dalam kegiatan akad, mencakup kualitas maupun kuantitas objek akad.

3) Riba, merupakan penambahan nilai barang sehingga pembayaran jumlah hutang bertambah.

4) Bațil, yaitu kegiatan jual beli yang rukun dan akadnya (ketentuan asal/ pokok dan sifatnya) tidak sesuai dengan syariat Islam.

5) Bay'i ma'dum, yaitu kegiatan perdagangan tetapi barang yang diperjual belikan belum

\footnotetext{
${ }^{26}$ Sudiarti.

${ }^{27}$ Sudiarti.

${ }^{28}$ Sudiarti.

${ }^{29}$ MUI, Fatwa Nomor: 80/DSN-MUI/III/2011, accessed February 18, 2021, https://www.ojk.go.id/id/kanal/syariah/regulasi/fat wa-dsn-mui/Pages/fatwa-nomor-80-dsn-mui-iii2011.aspx.
} 
ada. kegiatan ini masuk dalam jual beli gharar.

6) Ihtikar, yaitu kegiatan membeli barang pokok yang dibutuhkan masyarakat pada saat harga murah kemudian menimbunnya dan akan menjual kembali pada saat harga barang pokok tersebut naik/mahal.

7) Taghrir, yaitu upaya mempengaruhi orang lain, baik dengan ucapan maupun tindakan yang mengandung kebohongan, agar terdorong untuk melakukan transaksi.

8) Ghabn, memiliki arti pengurangan dimana tidak terjadi keseimbangan antara barang dengan harga barang tersebut, harga dapat lebih mahal atau lebih murah.

9) Talaqqi al-rukban, yaitu merupakan bagian dari ghabn, diman jual beli barang dengan harga yang lebih murah dibawah harga pasar dikarenakan pembeli barang tersebut membeli barang sebelum penjual sampai ke pasar sehingga penjual tidak mengetahui harga barang tersebut dipasar.

10) Tadlis, merupakan penipuan dalam transaksi jual beli karena penjual berusaha untuk menutupi kekurangan dari barang yang akan dijual

11) Tanajush/Najsh, merupakan tindakan yang menimbulkan kesan banyak yang berminat untuk membeli suatu barang dengan cara berpura-pura menawar barang dengan harga yang tinggi.

12) Dharar, merupakan suatu tindakan yang dapat menimbulkan bahaya atau kerugian bagi pihak lain.

13) Rishwah, memiliki arti hadiah, komisi atau suap yaitu memiliki tujuan untuk mengambil suatu hal yang bukan haknya sehingga menjadikannya bathil.

14) Maksiat dan zalim, yaitu perbuatan yang merugikan, mengambil atau menghalangi hak orang lain yang tidak dibenarkan secara syariah, sehingga dapat dianggap sebagai salah satu bentuk penganiayaan.

\section{Kesimpulan}

Foreign Direct Investment mempunyai dampak jangka pendek dan jangka panjang dalam perekonomian Indonesia. Dalam jangka pendek FDI belum begitu memberikan kontribusi yang cukup baik dalam perekonomian Indonesia, hal ini dikarenakan masih tingginya impor terhadap barang baku yang digunakan dalam produksi karena dianggap bahan baku dari Indonesia memiliki kualitas yang kurang bagus.

FDI dalam jangka panjang memberikan kontribusi yang bagus dalam perekonomian di Indonesia, dimana adanya FDI akan membuka lapangan pekerjaan bagi tenaga kerja terdidik hal ini dikarenakan adanya pendirian perusahaan dan pembangunan pabrik baru. Pemerintah Indonesia meyakini dengan adanya perusahaan dan pabrik-pabrik baru akan menyerap banyak tenaga kerja sehingga dapat meningkatkan pertumbuhan ekonomi.

Dalam Islam tidak terdapat pengertian investasi secara spesifik namun dalam Islam investasi merupakan suatu kegiatan/tindakan yang sangat disarankan kepada umat muslim, hal ini dikarenakan dengan adanya investasi yang dilakukan maka harta cenderung lebih berkembang/produktif dan dapat lebih bermanfaat bagi orang lain.

Dalam Islam juga tidak membedakan antara investasi asing langsung (FDI) maupun investasi domestik. Islam hanya mengatur bagaimana ketentuan atau tata cara dan kelola harta sesuai dengan syariat Islam. Selain itu islam juga mengatur apa yang harus dilaksanakan dan yang harus dihindari dalam kegiatan invetasi yang dilakukan oleh umat muslim.

\section{Daftar Pustaka}

Abul Hasan, Muhammad. Economic Development in Islam /Abulhasan Muhammad Sadeq. - National Library. Accessed February 11, 2021. https://www.nlb.gov.sg/biblio/5759644.

Adiwarman Karim. Ekonomi Islam Suatu Kajian 
Ekonomi Makro, 2002. http://library.umy.ac.id/koleksi/view/972 79/ekonomi-islam-suatu-kajiankontemporer.

Al-Jaziri, Abdurrahman. Al Fiqh Ala Al Madzahib Al Arba'ah, Juz 4,. Dar al Hadits, 2000.

Arsyad, Lincolin. Ekonomi Pembangunan Universitas Terbuka Repository. Accessed February 11, 2021. http://repository.ut.ac.id/3950/.

Azwar, Saifudin. Metode Penelitian. Accessed February 12, 2021. http://adl.aptik.or.id/default.aspx?tabID= $61 \& \mathrm{src}=\mathrm{k} \& \mathrm{id}=302766$.

Beik, Irfan Syauqi, and Laily Dwi Arsyianti. "Ekonomi Pembangunan Syariah," 2017, 266.

https://opac.perpusnas.go.id/DetailOpac. aspx?id=969369.

Eiteman, David K. "Penanaman Modal Asing Dan Penanaman Modal Dalam Negeri I Sere." Accessed February 11, 2021. https://sereeeias.wordpress.com/2013/0 5/31/penanaman-modal-asing-danpenanaman-modal-dalam-negeri/.

Feldstein, Martin. "Aspects of Global Economic Intergration: Outlook for the Future." NBER Working Papers, 2000. https://ideas.repec.org/p/nbr/nberwo/78 99.html.

Gregory, Mankiw. Makroekonomi Mankiw Edisi 6 Pdf 12, n.d.

Huda dkk, Nurul. Ekonomi Mikro Islam, Pendekatan Teoretis, 2018. http://library.um.ac.id/freecontents/index.php/buku/detail/ekonomi -makro-islam-pendekatan-teoretis-nurulhuda-et-al-34324.html.

Kurniati, Yati, Andry Prasmuko, and Yanfitri. "Determinan FDI (Faktor-Faktor Yang Menentukan Investasi Asing Langsung)." Bank of Indonesia Working Paper 6 (2007): 1-60.

Meier, Gerald. Leading Issues in Economic Development - Gerald M. Meier; James E.
Rauch - Oxford University Press. Accessed February 5, 2021. https://global.oup.com/academic/produc t/leading-issues-in-economicdevelopment9780195179606?cc=us\&lang=en\&.

MUI. Fatwa Nomor: 80/DSN-MUI/III/2011. Accessed February 18, 2021. https://www.ojk.go.id/id/kanal/syariah/r egulasi/fatwa-dsn-mui/Pages/fatwanomor-80-dsn-mui-iii-2011.aspx.

Puriadji, Annisa. "FDI Di Indonesia International Business Management." Accessed February 7, 2021. https://bbs.binus.ac.id/ibm/2017/11/fdidi-indonesia/.

Sabiq, Sayyid. Fiqh Sunnah 3 Trj. Mahyuddin Syaf. Al Ma\'arif, 1993.

Sudiarti, Sri. Fiqih Muamalah Kontemporer. Syariah Nurjati Press, 2018. https://www.academia.edu/download/51 037950/fiqih_muamalah_may.pdf\%0Ahtt ps://isbn.perpusnas.go.id/Account/Searc hBuku?searchCat=ISBN\&searchTxt=978602-14858-3-

5\%0Ahttp://repository.uinsu.ac.id/5517/ 1/FIQH MUAMALAH KONTEMPORER.pdf.

Suryawati. "Peran Investasi Asing Langsung Terhadap Pertumbuhan Ekonomi Di Negara-Negara Asia Timur" 5, no. 1 (1992): 8.

Todaro, Michael P. Pembangunan Ekonomi Di Dunia Ketiga Edisi Keenam. Alih Bahasa Oleh Haris Munandar, Penerbit Erlangga, Jakarta, 1997. https://books.google.co.id/books?id=M9 ofKAAACAAJ. 